\title{
ECOSYSTEM SERVICES AND FEDERAL PUBLIC LANDS: START-UP POLICY QUESTIONS AND RESEARCH NEEDS
}

\author{
J.B. RUHL*
}

INTRODUCTION

\begin{tabular}{|c|}
\hline FOR SALE \\
Ecosystem Services \\
From 650 Million Acres \\
Contact Secretary of \\
Interior or Agriculture Today! \\
\hline
\end{tabular}

It's unlikely you'll ever see a sign like this posted in front of the Department of Interior or Department of Agriculture buildings, but it is clear the federal government has come to the realization that it is sitting on a potentially vast repository of economic value in the form of ecosystem services from federal public lands. Ecosystem services are the economic benefits humans derive from the ecosystem structure and processes that form what might be thought of as natural

* Matthews \& Hawkins Professor of Property, The Florida State University College of Law, Tallahassee, Florida. I am thankful to the Duke Environmental Law \& Policy Forum for inviting me to participate in its 2009 symposium, Next Generation Conservation: The Government's Role in Emerging Ecosystem Service Markets, and for publishing this summary of my presentation and my notes from the panel on which I appeared. I also thank my fellow panelists and the panel moderator, Jim Salzman, for the valuable exchange we were able to achieve at the conference. I apologize for the frequent reference to other work of mine to elaborate what is said in the text. I do so only to provide annotations to my conference summary that lead to references by work of many others, not to suggest that my body of work on ecosystem services is the exclusive resource. Please direct any comments or questions to jbruhl@law.fsu.edu. 
capital. ${ }^{1}$ Ecosystem services flow to human communities in four streams: (1) provisioning services are commodities such as food, wood, fiber, and water; (2) regulating services moderate or control environmental conditions, such as flood control by wetlands, water purification by aquifers, and carbon sequestration by forests; (3) cultural services include recreation, education, and aesthetics; and (4) supporting services, such as nutrient cycling, soil formation, and primary production, make the previous three service streams possible. ${ }^{2}$ It makes sense that the federal government as the largest landowner in the nation, ${ }^{3}$ would begin to consider as a policy matter how it might manage the flow of ecosystem services on and off of its landholdings; yet it has only recently begun to do so in a coherent policy framework. ${ }^{4}$ Ecologists and economists have been forging the theory and application of the ecosystem services concept since the

1. Ecosystem services are economically valuable benefits humans derive from ecological resources directly, such as storm surge mitigation provided by coastal dunes and marshes, and indirectly, such as nutrient cycling that supports crop production. Natural capital consists of the ecological resources that produce these service values, such as forests, riparian habitat, and wetlands. For descriptions of natural capital and ecosystem services, see MILLENNIUM ECOSYSTEM ASSESSMENT, ECOSYSTEMS AND HUMAN WELL-BEING: SYNTHESIS (2005), available at http://www.millenniumassessment.org/documents/document.356.aspx.pdf; NATURE's SERVICES: SOCIETAL DEPENDENCE ON NATURAL ECOSYSTEMS (Gretchen C. Daily ed. 1997) [hereinafter NATURE's SERVICES]; Robert Costanza et al., The Value of the World's Ecosystem Services and Natural Capital, 387 NATURE 253 (1997). For coverage of the emergence of the ecosystem services concept in law and policy, see J.B. RUHL, STEVEN E. KrafT \& Christopher L. LANT, THE LAW AND POLICY OF ECOSYSTEM SERVICES (Island Press 2007) [hereinafter LAW AND POLICY]; J.B. Ruhl \& James Salzman, The Law and Policy Beginnings of Ecosystem Services, 22 J. LAND USE \& ENVTL. L. 157 (2007) [hereinafter Law and Policy Beginnings]; James Salzman, A Field of Green? The Past and Future of Ecosystem Services, 21 J. LAND USE AND ENVTL. L. 133 (2006).

2. This typology of ecosystem services is developed in MiLlENNIUM ECOSYSTEM ASSESSMENT, supra note 1 , at vi.

3. "The federal government owns about 30 percent of the nation's total surface area (about 650 million acres). Four major federal land management agencies-the Forest Service, Bureau of Land Management, Fish and Wildlife Service, and National Park Service-are responsible for managing about 95 percent of these lands. The Department of Defense manages most of the remainder." U.S. GEN. ACCOUNTING OFFICE, RCED-96-40, LAND OWNERSHIP: INFORMATION ON THE ACREAGE, MANAGEMENT, AND USE OF FEDERAL AND OTHER LANDS 2 (1996) [hereinafter LAND OWNERSHIP].

4. I should add that, of course, important ecosystem services flow within and from the marine environment over which the federal government has dominion. See Charles H. Paterson \& Jane Lubcheco, Marine Ecosystem Services, in NATURE's SERVICES, supra note 1, at 215. My focus is on the federal government's inland holdings and their associated resources. Coastal regions, which fit my focus, also are tremendous sources of ecosystem services. See Elise F. Granek et al., Ecosystem Services as a Common Language for Coastal Ecosystem-Based Management, 24 CONSERVATION BIOLOGY 207 (2010). 
mid-1990s, ${ }^{5}$ but only in the past few years has the concept begun to register in federal public lands policy in any meaningful way. ${ }^{6}$

This Essay, based on my presentation at Duke Law School's 2009 symposium, Next Generation Conservation: The Government's Role in Emerging Ecosystem Service Markets, ${ }^{7}$ briefly examines this emerging policy front and proposes a set of key policy questions, research needs, and options for building on the policy work that has been done to date. Part I outlines the basic context for thinking about the role federal public lands might play in the management of ecosystem services, and why using the ecosystem services concept in public land policy is worth considering. Part II proposes several key research paths that must be addressed before federal lands can be managed effectively for ecosystem service flows. Part III bears down on the different roles federal lands might play in promoting or participating in markets for ecosystem services. My goal is not to propose any particular policy for federal lands and ecosystem services, but rather to suggest how federal public land management agencies should go about formulating and implementing such policies. Who knows, someday the cry might be "there's ecosystem services in them thar hills," in which case the federal government should have a plan for how we get to them.

\section{KEY THRESHOLD CONSIDERATIONS}

Three disciplines merge at the core of the concept of ecosystem services: ecology, to understand the ecological structures and processes that produce and deliver ecosystem services; economics, to understand how those delivered ecosystem services provide value to human beneficiaries; and geography, to understand where the "natural capital" providing services is located, where the beneficiaries

5. See Law and Policy Beginnings, supra note 1, at 158-61 (2007); Harold A Mooney \& Paul R. Erlich, Ecosystem Services: A Fragmentary History, in NATURE'S SERVICES, supra note 1 , at 11 .

6. See LAW AND POLICY, supra note 1, at 127-57; Law and Policy Beginnings, supra note 1 , at $163-64$.

7. J.B. Ruhl, Matthew \& Hawkins Professor of Prop., Fla. St. Univ., Address at the Duke Law \& Policy Forum Symposium: Next Generation Conservation: The Government's Role in Emerging Ecosystem Service Markets (Oct. 23, 2009) available at http://www.law.duke.edu/ webcast.

8. The origin of the famous line, "There's gold in them thar hills," is unknown but a close approximation dates back to the 1939 Warner Brothers Merrie Melodies cartoon, GOLD RUSH DAZE, which can be viewed at a number of YouTube sites. See GOLD RusH DAZE (Warner Brothers Pictures 1939), available at http://www.youtube.com/watch?v=WdQgq_S9TWc. 
of ecosystem services are located, and how the services flow from the former to the latter.' The federal land management agencies already deploy expertise in each of these fields to carry out their statutory duties, such as deciding where to allow recreation, timber harvesting, and mineral exploration in national forests. The agencies also already include providing values to the public as part of their respective missions. Indeed, without calling them such, the agencies have been providing ecosystem services to the public for many decades in the form of provisioning services (e.g., timber from national forests and water from reclamation projects), regulating services (e.g., watershed protection from national forests), cultural services (e.g., recreation and education in national parks), and supporting services (e.g., nutrient cycling in wetlands on federal lands).

So what difference will it make to think explicitly about the concept of ecosystem services when formulating federal land management policy? Good question. To answer it-to appreciate how the concept of ecosystem services can reorient and clarify federal land management policy-we need to step back and consider how the central properties of ecosystem services connect with the context of federal public land policy.

\section{A. Defining Management Missions}

A fundamental starting point for designing ecosystem services policy is that the concept of ecosystem services is anthropogenic in focus-it is about delivering economic value to humans. As noted, federal land policy already does so in many ways through the management responsibilities and goals assigned to the major land management agencies.

Each of the four major federal land management agencies manages its lands and the resources they contain on the basis of its mission and responsibilities. The Forest Service and the Bureau of Land Management manage lands for a variety of uses, including recreation, timber harvesting, livestock grazing, oil and gas production, mining, and wilderness protection. The Fish and Wildlife Service manages lands primarily to conserve and protect fish and wildlife and their habitat, although other uses, such as hunting and fishing, are allowed when they are compatible with the primary purposes for which the lands are managed. The National 
Park Service manages lands to conserve, preserve, protect, and interpret the nation's natural, cultural, and historic resources. ${ }^{10}$

If the land management agencies were to orient their missions around ecosystem services, however, this description of what the agencies do would look quite different. For example, the description might employ the four typology categories to arrange the different management goals. Also, in each case it would be necessary to identify the intended human beneficiaries. For example, the Bureau of Land Management would be described as focused on delivering provisioning services to the public in general through access given to commodity producers, whereas the Fish and Wildlife Service would provide on-site cultural services such as education about endangered species and hunting. Using ecosystem services to inform the agencies' work also would supply a new metric for agency mission description and performance evaluation, as well as making the federal public lands' economic value to society more explicit to the public. Clearly, therefore, employing the ecosystem services concept in federal land policy would lead to a different way of describing what the land management agencies do and how well they do it.

\section{B. Public Goals and Public Lands}

The consequence of using the ecosystem services approach as described above, however, is that there must be economic value delivered to humans for there to be ecosystem services. Yet providing economic value to humans may not be the only goal we have for federal public lands. Or, to put it more in focus, maximizing economic value to humans is likely not the overarching goal we have for all of our federal public lands. For example, setting aside land for wilderness or managing land to protect an endangered species might provide some ecosystem services, such as benefits to local human populations from the watershed functions of the conserved lands, but only as an incidental effect of implementing the conservation goal.

In this sense, what public land policy does with the concept of ecosystem services will be fundamentally different from how the concept can be employed to improve the use of private lands. In the private lands context, the concept of ecosystem services improves the market information available to landowners in deciding what constitutes the most efficient use of the land and its associated

10. LAND OWNERSHIP, supra note 3, at 2 . 
resources. ${ }^{11}$ Of course, to take advantage of that information, private landowners need some way of capturing the value of the services in markets, which is difficult for services like pollination from wild pollinators and groundwater recharge of aquifers from wetlands. ${ }^{12}$ Thus the challenge in the private lands context is how to integrate ecosystem service values into market contexts. ${ }^{13}$

The point of having public lands, by contrast, is that we don't have to manage them like private lands-that is, the public can decide, using non-market decision mechanisms if we so choose, to suspend the goal of achieving the most efficient economic outcome. So, when considering how to incorporate the concept of ecosystem services into federal land management policy, it will be important for Congress and the agencies to define precisely how far we are taking it and in what contexts this is not a desirable medium for expressing agency mission and assessing agency performance. It might be useful, for example, for agencies to describe the incidental ecosystem service benefits of preserving habitat for endangered species, but if the goal is preserving habitat for endangered species, the concept of ecosystem services has little if any useful direct role to play, and could even be counterproductive if used to define the policy means and outcome. ${ }^{14}$

\section{Offsite Delivery of Regulating and Supporting Services}

If we were to describe what benefits federal lands provide under current policy through the lens of ecosystem services, two forms of

11. See Christopher L. Lant, J.B. Ruhl, and Steven E. Kraft, The Tragedy of Ecosystem Services, 58 BIOSCIENCE 969, 970-71 (2008).

12. The extensive literature on the economics of ecosystem services given their status as public goods is surveyed in LAW AND POLICY, supra note 1, at 57-83.

13. See James Salzman, Creating Markets for Ecosystem Services: Notes from the Field, 80 NYU L. REV. 870, 883 (2005).

14. Going even further, some commentators express deep concern over the effect the concept of ecosystem services may have on public perceptions of ecological function and conservation of ecological integrity as a sufficient policy goal, in the sense that commodifying the ecosystem function into the metrics of economic service value may decouple the public's perception of the service from the underlying ecological processes. See Marcus J. Peterson et al., Obscuring Ecosystem Function with Application of the Ecosystem Services Concept, 24 Conservation Biology 113, 114 (2009); Kent H. Redford \& William M. Adams, Payment for Ecosystem Services and the Challenge of Saving Nature, 23 CONSERVATION BIOLOGY 785, 785 (2009). Others counter that the concept of ecosystem services has been employed to rebut economic justifications for activities antithetical to conservation and to open up new conservation opportunities that would not likely be accomplished by relying on purely intrinsic and scientific justifications for conservation. See Matt Skroch \& Laura Lopez-Hoffman, Saving Nature under the Big Tent of Ecosystem Services: A Response to Adams and Redford, 24 CONSERVATION BIOLOGY 325, 325 (2009). 
services would be well represented in the inventory. One is on-site delivery of cultural services, such as recreation in parks and hunting in wildlife refuges. The other is delivery of provisioning services for off-site use, such as timber and water supply. Along with these, of course, are the regulating and supporting services provided within the federal public lands to facilitate and complement policies focused on delivering the cultural and provisioning services. The federal public lands have been managed for decades to include delivering these cultural and provisioning services, and it is not clear how calling hunting a cultural service and timber a provisioning service will fundamentally alter how the land management agencies go about their work. ${ }^{15}$

But what about delivery of regulating and supporting services to offsite human populations? This is fertile ground for using the concept of ecosystem services to reorient and clarify federal land policy. This is the context in which ecosystem services offer the greatest opportunity to define agency mission, communicate the value of the federal lands to the public, and measure agency performance. Presumably, it would not be news to most people that federal public lands can benefit surrounding and even distant human populations, including in ways consistent with ecosystem services theory. But the existing and potential flow of services is vast and has not been coherently managed and communicated as such. This context, it strikes me, is where the greatest payoffs and challenges lie for incorporating ecosystem services into federal public land management policy. The next section explores how to manage that start-up process for regulating and supporting services.

\section{POLICY QUESTIONS AND RESEARCH NEEDS}

Before we can formulate policy for ecosystem services on federal land, the agencies will need to define which resources provide or potentially provide which services, who benefits or potentially benefits from the services, and the extent of policy discretion allowed in the relevant legal framework applicable to the lands under study.

15. Indeed, in general I find little to be gained in domestic public or private land management contexts by describing commodities such as corn or timber as provisioning services and activities such as hunting and fishing as cultural services. Markets obviously already exist for these services in the private lands context, and public policy has for decades hashed out how they are delivered on public lands. See George CAmeron Coggins et AL., Federal Public LAND AND RESOURCES LAW passim (6 $6^{\text {th }}$ ed., 2007). 


\section{A. Establish Baselines}

One can download countless maps of federal public lands showing all sorts of different attributes-elevation, land cover, species distribution, and so on-yet there is no map of the regulating and supporting services they provide to offsite human communities. ${ }^{16}$ Before the land management agencies can begin to think clearly about developing and implementing ecosystem service based policies, such a baseline representation is needed. The baseline must accomplish the following:

- Inventory onsite and offsite natural capital that can be supported.

- Identify offsite flows of current and potential regulating and supporting services.

- Identify offsite human populations receiving current and potential service values.

- Inventory service values to those populations with appropriate valuation methods.

Research of this scope is only beginning to gain funding and attention in the federal agencies, ${ }^{17}$ and is even less developed with respect to federal public lands. There is a strong consensus that "the

16. At least I couldn't find one.

17. For example, the EPA's Office of Research and Development in 2007 began planning such studies on wetlands as a major component of its Ecosystem Services Research Program (ESRP). See U.S. EPA, RESEARCH TO VALUE ECOSYSTEM SERVICES IDENTIFYING, QUANTIFYING, AND ASSESSING NATURE'S BENEFITS (2007) (discussing the importance of ecosystem services in researching wetlands), available at http://epa.gov/ord/esrp/pdfs/ESRPoverview-fact-sheet-final.pdf. This research provides a foundation to enable the assessment of an array of core ecosystem services provided by freshwater and coastal wetlands. See id. (stating that this new wetland research will determine how the position of wetlands on the landscape alters the provision of ecosystem services). In addition, ESRP research is developing methods to quantitatively assess other regulating and supporting services from wetlands, including flood control and storm surge protection, maintenance of water quality, nutrient cycling, and carbon storage and sequestration. See U.S. EPA, ECOSYSTEM SERVICES RESEARCH FOCUSES ON WETLANDS (2007), available at http://www.epa.gov/ORD/npd/pdfs/ erp-place-based-research_wetlands-factsheet.pdf (discussing the range of benefits gained from wetland ecosystems that contribute to human well-being); U.S. EPA, Ecosystem Services Research Program: Basic Information, http://epa.gov/ord/esrp/basic-info.htm (last visited Jan. 20, 2010) (discussing the future research of the ESRP is designed to measure and assess these ecosystem services). This line of research is expected to prove very useful in private lands regulatory contexts such as wetlands conservation, see J.B. Ruhl, James Salzman, and Iris Goodman, Implementing the New Ecosystem Services Mandate of Section 404 of the Compensatory Mitigation Program-A Catalyst for Advancing Science and Policy, 38 STETSON L. REV. 251, 269-70 (2009), and there is no reason not to believe the same for public lands. 
science of ecosystem services needs to advance rapidly" through these and other initiatives. ${ }^{18}$

\section{B. Identify Tradeoffs}

As the baseline is pulled together, federal land management agencies can begin to answer three foundational questions: what services can the land unit provide, what populations can be benefitted, and when can they be benefitted? The answers, however, are in many instances likely to reveal a complex multi-scalar mosaic of ecosystem service potentials. For example, Table 1 shows how a hypothetical national forest might compile the following inventory of ecosystem service possibilities: ${ }^{19}$

Table 1. Forest Ecosystem Services

\begin{tabular}{|l|l|}
\hline Forest Ecosystem Service & Population Benefitted and Timing \\
\hline Carbon sequestration & Global; lagged \\
\hline Surface Water quality & Region A; immediate \\
\hline Groundwater recharge & Region B; fluctuating \\
\hline Microclimate & Locality C; fluctuating \\
\hline Pollination & Farm D; immediate \\
\hline
\end{tabular}

It is immediately apparent from this example that policy decisions about how to manage the production of ecosystem services from this land unit face a suite of five potential tradeoffs: ${ }^{20}$

18. Gretchen C. Daily, Ecosystem Services in Decision Making: Time to Deliver, 7 FRONTIERS IN ECOLOGY AND ENVIRONMENT 21, 21 (2009).

19. For background on forest ecosystem services, see Norman Myers, The World's Forests and Their Ecosystem Services, in NATURE'S SERVICES, supra note 1, at 215.

20. For a general discussion of these tradeoffs, see LAW AND POLICY, supra note 1, at 3233; Millennium Ecosystem Assessment, supra note 1, at 6-20; Erik Nelson et al., Modeling Multiple Ecosystem Services, Biodiversity Conservation, Commodity Production, and Tradeoffs at Landscape Scales, 7 FronTIERS IN ECOLOGY AND ENVIRONMENT 4, 4-10 (2009). The five trade-off categories summarized in the text are derived from this set of sources. 
1. Service tradeoffs: It may not be possible to manage land units for all the potential services, as the underlying ecological processes that are the source of the services may put one service in competition with another. For example, maximizing the hypothetical land unit for carbon sequestration may involve vegetative management practices that diminish the supply of habitat for pollinators, and vice versa. Which service should be the primary management goal?

2. Spatial policy tradeoffs: As the example suggests, moreover, different services operate at different spatial policy scales. Carbon sequestration serves national climate mitigation policy goals, whereas pollination operates primarily on local or parcel scales. If services flowing at different spatial scales experience tradeoffs, then so too do the corresponding policies. Which policy scale should the agency target?

3. Temporal policy tradeoffs: Similarly, different services have different delivery mechanisms and timing. It may be, for example, that habitat manipulation on the land unit can boost pollination services rather quickly, whereas doing so to promote carbon sequestration produces results only relatively far into the future. Should the agency seek immediate payoffs or pursue the long-term strategy?

4. Goal tradeoffs: As suggested above, managing public lands for ecosystem services may not always be compatible with other goals for public lands. It is unlikely, for example, that the most effective way to manage lands for the benefit of endangered species will align well with the most effective way to maximize ecosystem service flows from those lands to human populations. Which goal should the agency pursue?

5. Population tradeoffs: Inherent in all of these tradeoffs is the possibility that very different populations may benefit depending on the policy decisions about which service, spatial scale, and temporal scale to favor. Carbon sequestration on a national forest benefits a global population; pollination services from the forest might directly benefit just a few area farms and indirectly benefit the consumers of their crops; and endangered species conservation benefits, in addition to the species, people interested in endangered species conservation. Which 
population should the agency favor if the services and scales are not compatible? This could become a particularly acute problem if the wealth transfer-i.e., the enhancement of one service benefitting a particular population at the expense of another service benefitting another population-favors the wealthy over the poor.

Federal public lands management already faces numerous policy and scale tradeoffs - it is difficult to hike in an active timber cut or conserve endangered species habitat in an active grazing lease. Whole courses in law schools are devoted to studying how Congress and the land management agencies wrestle with these difficult choices. $^{21}$ Ironically, integrating ecosystem services into public land management policy and building robust baseline inventories will only reveal more trade-offs, and likely on larger scales given the focus on offsite benefits. ${ }^{22}$

\section{Identify Legal Authorities and Constraints}

Some of the tradeoff challenges of ecosystem services policy formulation will be mooted or amplified depending on the legal constraints associated with different land units in the federal public land system. Broadly speaking, federal public lands can be lumped into three categories based on the range of uses allowed under applicable statutes. ${ }^{23}$ Single use lands such as wilderness areas have a narrowly defined purpose that cannot be violated. ${ }^{24}$ A wilderness area, therefore, is not a candidate for managing for services such as pollination or carbon sequestration, though those or other services may flow incidentally from management as a wilderness area. Primary use lands such as national wildlife refuges have a defined priority use or uses, but others are allowed if compatible with the primary use or uses. ${ }^{25}$ There may be many such opportunities on a refuge to enhance offsite service flows while not impeding purposes

\footnotetext{
21. See, e.g., COGGINS ET AL., supra note 15.

22. Environmental markets such as wetlands mitigation banking have been shown, for example, to shift ecosystem services across the landscape if the service values are not accounted for in the market "currency" system, which in the case of wetlands mitigation banking focuses on acres and ecological function. See J.B. Ruhl and James Salzman, The Effect of Wetlands Mitigation Banking on People, 28 NAT. WeTLANDS NEWSL. 1, 1 (2006).

23. This typology of federal public land management mandates is discussed in more detail in John Copeland NAgle \& J.B. Ruhl, The LAW OF Biodiversity AND ECOSYstem MANAGEMENT 393-95 (2d ed., 2006).
}

24. $I d$.

25. Id. 
such as onsite waterfowl habitat conservation. Multiple use lands such as national forests require the managing agency to fulfill a range of uses, some of which may be conflicting and impossible to accomplish in the same area of the land unit. ${ }^{26}$ As summarized in Table 2, multiple use lands thus hold the greatest potential for management focusing on offsite delivery of regulating and supporting services, but as a consequence they also present the greatest chance of facing tradeoffs between competing services, policies, and populations. With discretion comes the heat from making choices that favor one interest group over another.

Table 2. Categories of Land Management Mandates

\begin{tabular}{|l|l|l|}
\hline $\begin{array}{l}\text { Land Management } \\
\text { Mandate }\end{array}$ & Legal Constraints & $\begin{array}{l}\text { Ecosystem Service } \\
\text { Policy Options }\end{array}$ \\
\hline $\begin{array}{l}\text { Single Use } \\
\text { (e.g., Wilderness) }\end{array}$ & $\begin{array}{l}\text { All management } \\
\text { actions must satisfy } \\
\text { single use purpose; } \\
\text { restricted agency } \\
\text { discretion }\end{array}$ & $\begin{array}{l}\text { Manage for wilderness } \\
\text { and inventory the } \\
\text { baseline services and } \\
\text { beneficiaries }\end{array}$ \\
\hline $\begin{array}{l}\text { Primary Use } \\
\text { (e.g., National Wildlife } \\
\text { Refuges) }\end{array}$ & $\begin{array}{l}\text { Other uses must not be } \\
\text { inconsistent with the } \\
\text { primary use; limited } \\
\text { agency discretion }\end{array}$ & $\begin{array}{l}\text { Identify services that } \\
\text { can be enhanced } \\
\text { within the primary } \\
\text { purpose constraint; } \\
\text { manage for them }\end{array}$ \\
\hline $\begin{array}{l}\text { Multiple Use } \\
\text { (e.g., National Forests) }\end{array}$ & $\begin{array}{l}\text { The multiple uses } \\
\text { must be balanced; } \\
\text { extensive agency } \\
\text { discretion }\end{array}$ & $\begin{array}{l}\text { Integrate service } \\
\text { valuation more } \\
\text { explicitly in multiple } \\
\text { use decision making; } \\
\text { manage for them }\end{array}$ \\
\hline
\end{tabular}

\section{FEDERAL LANDS AND ECOSYSTEM SERVICE MARKETS}

The Duke Law School conference at which I outlined the foregoing policy and research framework focused in particular on a type of policy option for ecosystem services on federal landfacilitating or participating in ecosystem service markets. Not long 
before the conference, the 2008 Farm Bill took a bold step in this direction. Section 2709 of the Food, Conservation, and Energy Act of 2008 requires the Department of Agriculture to "establish technical guidelines that outline science-based methods to measure the environmental services benefits from conservation and land management activities in order to facilitate the participation of farmers, ranchers, and forest landowners in emerging environmental services markets" and to establish guidelines to develop a procedure to measure environmental services benefits, a protocol to report environmental services benefits, and a registry to collect, record and maintain the benefits measured. ${ }^{27}$ To implement section 2709 of the Farm Bill, the Forest Service established an Office of Ecosystem Services and Markets, now known as the Office of Environmental Markets. A multi-agency Conservation and Land Management Environmental Services Board was established in December 2008 to assist the Secretary of Agriculture in adopting the technical guidelines to assess ecosystem services provided by conservation and land management activities. ${ }^{28}$ The Board's guidelines are intended to focus on scientifically rigorous and economically sound methods for quantifying carbon, air and water quality, wetlands, and endangered species benefits in an effort to facilitate the participation of farmers, ranchers, and forest landowners in emerging ecosystem markets. ${ }^{29}$

While the Farm Bill is focused on how the Department of Agriculture can promote ecosystem service markets for farmers, ranchers, and forest landowners, it tantalizingly opens the door to thinking about the broader role of federal public lands as an integral part of ecosystem services markets. Take, for example, a national forest unit that could deliver groundwater recharge services to a regional population or carbon sequestration services to a national population. Assume that private lands near the national forest also can supply those services. Assume also that there is an emerging or even robust demand in the region or nation for those servicesenough to potentially give rise to a market for them. What policy options are available to the national forest management team? The

27. Food, Conservation \& Energy Act of 2008, H.R. 2419, 110th Cong. § 2709 (2008).

28. OFFICE of ENVIRoNmental Markets, U.S. Dep'T OF Agric., ECOSYSTEMS AND THE FARM BILL, http://www.fs.fed.us/ecosystemservices/Farm_Bill/index.shtml (last visited March 31, 2010).

29. See Conservation and Land Management Environmental Services Board Charter 1-2, available at $\mathrm{http}: / /$ www.fs.fed.us/ecosystemservices/pdf/farmbill/ESB_Charter.pdf (last visited May 30, 2010). 
various speakers at the conference converged around the following set of options, arranged in ascending order of active market facilitation and participation: ${ }^{30}$

1. Do nothing: One option, of course, is to do nothing with respect to potential or active markets for ecosystem services, but rather to manage public land units for ecosystem services according to applicable policy goals. To the extent that the policy decision is to provide offsite regulating and supporting services at a particular level, they will be provided essentially for free to the beneficiaries and thus will decrease the market prices that private suppliers can demand.

2. Provide research subsidies: To the extent that the federal government wishes to promote the emergence of active private markets in ecosystem services, one policy approach could be to use public lands and agency budgets to conduct the research necessary to define crucial market parameters, such as how to promote groundwater recharge through vegetative management or how much wetland surface area is needed to control particular flood levels. Such research may be expensive to conduct and thus may operate as a barrier to emergence of what might, with the knowledge the research could reveal, become efficiently operating private markets.

3. Conduct demonstration projects: Going a step further, an agency could decide to use a public land unit to experiment with different methods of delivering offsite ecosystem services and measuring the economic benefits, in essence acting as a surrogate for a first mover in the potential market.

4. Provide market stability through standards and risk assurance: Support for private markets could also come in the form of more direct involvement, such as by promulgating or endorsing practices and standards, and even backing private market obligations as a market insurance mechanism. For example, if market development is hindered by risks associated with private supplier failure due to drought

30. This list is a synthesis of my notes from the conference and includes observations made by many of the speakers, none of whom I purport to identify with any particular aspect of the list. I thank all the participants for their illuminating comments and take no credit for any wisdom revealed in my summary, nor do I represent that any particular speaker endorsed or questioned any point made in my list. I recommend that anyone interested in this topic view the conference video. 2009 DELPF Symposium - part 1 (Oct. 23, 2009) available at: http:// www.law.duke.edu/webcast (last visited June 2, 2010). 
(leading to failure to supply recharge) or fire (leading to leakage of carbon sequestration), the federal government could use appropriately located public lands to offer supply assurance.

5. Provide a third-party market platform: Once active markets for ecosystem services exist, federal public lands could also be leased or licensed to third parties to produce and market offsite ecosystem services. In practice, this is how federal lands produce provisioning services such as timber and cattle-private producers obtain permits and leases to occupy the public lands and produce commodities for sale in private markets. Federal lands also are venues for private recreation concessions such as ski centers and outfitters. Third party markets for regulating and supporting services could be developed on federal public lands in much the same way.

6. Act as a full market participant: The most aggressive form of market support for federal public lands would be for the federal agencies to assume a proprietary role and enter the market as full participants using the federal land units as the production capital.

Which of these options best meets and balances public land policy goals and national goals for ecosystem services and for ecological conservation will depend on the services involved, the public land unit, and the policy tradeoffs discussed above. One theme that came out loud and clear at the Duke Law School conference in this respect was the mounting tension between carbon sequestration-currently the major player in ecosystem service market policy development-and the other services and values that could be delivered from public lands, whether through markets or not. ${ }^{31}$ On the one hand, the concern expressed was that the focus on carbon markets and the role of federal public lands in them could swamp policy regarding other service flows. ${ }^{32}$ On the other hand, there was strong representation of the sentiment that carbon sequestration is the only ecosystem services market game in town, so to speak, and helping it emerge and prosper could ignite similar markets in other ecosystem services. ${ }^{33}$ At the dawn of federal public

\footnotetext{
31. See id.

32. See id.

33. See id.
} 
lands policy for ecosystem services, navigating between these two perspectives will be a profound policy challenge.

\section{CONCLUSION}

As Associate Chief of the Forest Service, Sally Collins, more recently the head of the USDA's Office of Environmental Markets, cautioned that the agency must "resist the impulse to jump on the ecosystem services 'bandwagon' without some thinking." "34 That has been the spirit behind this short exposition on how to advance such thinking. The Duke Law School conference was a tremendous gathering of expertise in that respect, and I have not purported to eclipse what was forged there in the way of theoretical and practical thinking, but rather hope only to have summarized and synthesized. Overall, the conference revealed a tremendous potential for federal public lands to contribute to the future of ecosystem services law and policy. Tremendous challenges also exist, however, and ecosystem services will not be the silver bullet to solve all the federal public land policy woes. It will take clear policy thinking and focused ecological, economic, and geographic research to unlock the potential and avoid the pitfalls, but in my estimation the upside more than justifies the effort.

34. Sally Collins \& Elizabeth Larry, U.S. Forest Service, Caring for Our NAtural Assets: An EcOSYSTem Services Perspective 8 (2007), available at http:// www.fs.fed.us/ecosystemservices/pdf/collins_larry.pdf. 